\title{
A Novel Series of Sialic Acid-Based Influenza Virus Inhibitors that Target Influenza Virus Neuraminidase ${ }^{\dagger}$
}

\author{
Mark von Itzstein \\ Institute for Glycomics, Griffith University, Gold Coast, Queensland 4222, Australia; \\ m.vonitzstein@griffith.edu.au \\ + Presented at the 2nd Molecules Medicinal Chemistry Symposium (MMCS): Facing Novel Challenges in \\ Drug Discovery, Barcelona, Spain, 15-17 May 2019.
}

Published: 7 August 2019

Keywords: Influenza; Neuraminidase; Inhibitors

Influenza virus continues to be a clinically-significant human pathogen that causes both epidemics and pandemics. Successful inhibition of the viral neuraminidase hinders the release of virion progeny from the infected host cell and significantly reduces further virus spread.

We recently described the discovery of highly potent sialosyl sulfonate inhibitors of influenza virus sialidase [1,2]. One of the designed sialosyl $\alpha$-sulfonate derivatives is a nanomolar inhibitor ${ }^{2}$ in a cell-based influenza virus replication assay and has comparable activity to that of anti-influenza drugs zanamivir and the active form of oseltamivir, oseltamivir carboxylate.

Finally, we undertook a protein X-ray crystallographic study that provides atomic-level detail of the binding mode of these sialosyl $\alpha$-sulfonate derivatives [2].

\section{References}

1. Hadházi, Á.; Pascolutti, M.; Bailly, B.; Dyason, J.C.; Borbás, A.; Thomson, R.J.; von Itzstein, M.; A sialosyl sulfonate as a potent inhibitor of influenza virus replication Org. Biomol. Chem. 2017, 15, 5249-5253.

2. Hadházi, Á.; Li, L.; Bailly, B.; Maggioni, A.; Martin, G.; Dirr, L.; Dyason, J.C.; Thomson, R.J;; Gao, G.F.; Borbás, A.; et al. A Sulfonozanamivir Analogue Has Potent Anti-influenza Virus Activity ChemMedChem 2018, 13, 785-789.

(C) 2019 by the authors. Licensee MDPI, Basel, Switzerland. This article is an open access article distributed under the terms and conditions of the Creative Commons Attribution (CC BY) license (http://creativecommons.org/licenses/by/4.0/). 